\title{
MODELLING OF HABITAT CONDITIONS \\ BY SELF-ORGANIZING FEATURE MAPS USING RELATIONS BETWEEN SOIL, PLANT CHEMICAL PROPERTIES AND TYPE OF BASALTOIDES
}

\author{
Piotr KosibA*, ANDRZEJ StAnKIEWICZ, Lucyna Mróz \\ Department of Ecology, Biogeochemistry and Environmental Protection, \\ Institute of Plant Biology, Wroclaw University \\ Kanonia 6/8, 50-328 Wrocław, Poland \\ *e-mail: kosibap@biol.uni.wroc.pl
}

(Received: February 3, 2010. Accepted: August 11, 2010)

\begin{abstract}
The paper shows the use of Kohonen's network for classification of basaltoides on the base of chemical properties of soils and Polypodium vulgare L. The study area was Lower Silesia (Poland). The archival data were: chemical composition of types of basaltoides from 89 sites $\left(\mathrm{Al}_{2} \mathrm{O}_{3}, \mathrm{CaO}, \mathrm{FeO}, \mathrm{Fe}_{2} \mathrm{O}_{3}, \mathrm{~K}_{2} \mathrm{O}, \mathrm{MgO}, \mathrm{MnO}, \mathrm{Na}_{2} \mathrm{O}, \mathrm{P}_{2} \mathrm{O}_{5}\right.$, $\mathrm{SiO}_{2}$ and $\mathrm{TiO}_{2}$ ), elements contents in soils $(\mathrm{Cd}, \mathrm{Co}, \mathrm{Cu}, \mathrm{Fe}, \mathrm{Mn}, \mathrm{Mo}, \mathrm{Ni}, \mathrm{Pb}, \mathrm{S}$, Ti and $\mathrm{Zn})$ and leaves of $P$. vulgare $(\mathrm{Ca}, \mathrm{Cd}, \mathrm{Co}, \mathrm{Cu}, \mathrm{Fe}, \mathrm{K}, \mathrm{Mg}, \mathrm{Mn}, \mathrm{Mo}, \mathrm{N}, \mathrm{Ni}, \mathrm{P}, \mathrm{Pb}, \mathrm{S}, \mathrm{Ti}$ and $\mathrm{Zn}$ ) from 20 sites. Descriptive statistical parameters of soils and leaves chemical properties have been shown, statistical analyses using ANOVA and relationships between chemical elements were carried out, and SOFM models have been constructed. The study revealed that the ordination of individuals and groups of neurons in topological maps of plant and soil chemical properties are similar. The constructed models are related with significantly different contents of elements in plants and soils. These models represent different chemical types of soils and are connected with ordination of types of basaltoides worked out by SOFM model of TAS division. The SOFM appeared to be a useful technique for ordination of ecological data and provides a novel framework for the discovery and forecasting of ecosystem properties.
\end{abstract}

KEY WORDS: SOFM, basaltoides, Polypodium vulgare, ecological modelling, habitat conditions.

\section{INTRODUCTION}

Nowadays, particular attention is being paid to search of methods and solutions enabling higher verification possibilities of study results. Researchers use a lot of numerical methods, mainly classical ones (Sokal and Rohlf 2003), but also techniques based on artificial neural networks (ANNs) (Ray and Klindworth 2000; Sokołowski 2002; Tadeusiewicz 2006). Furthermore, Moreno-Sanches (2004) points to the use of various image and numerical techniques, which are precise and practical in ecological studies and Sokołowski (2010) points to the abundance of basic and advanced statistical methods in research. Their use in order to recognize the regularities occurring in phenomenons and processes remaining under the influence of the main reasons (systematic component) and indirect ones (accidental component) (Sokołowski 2010).

In case of environmental studies, ANNs provide an effective alternative to conventional modelling techniques (Scardi 2001). Moreover, Tadeusiewicz (2000) draws attention to the application of neural networks in biotechnology and biomaterials, which offer an attractive solution to lots of problems in many critical applications, and Kosi- ba (2010; and other references cited by this author) to their superiority to classical and advanced statistical methods in case of ecological studies. One of the ANNs is Kohonen's network (Kohonen 2001), which can be used for ordination and visualization of complex ecological data (Chon et al. 1996; Recknagel 2001).

The soils in the area of Lower Silesia formed from basalts (Adamczyk 2008), are overgrown with common but also unique and protected vegetation (Mróz 2001; Fabiszewski and Kwiatkowski 2002; Stankiewicz and Kosiba 2009; and other references cited by these authors), for example lithophytes, among which the chasmophytes are of particular importance and do not appear beyond those types of soils: Asplenium septentrionale, A. trichomanes, Polypodium vulgare, Dryopteris filix-mas, Sedum acre, Thymus pulegioides, Hieracium pilosella. These soils contain different levels of elements, in particular heavy metals and offer special conditions for those plant species.

This paper is the second part of ecological modelling by Self-Organizing Feature Maps (SOFM) on classification of habitat quality (Stankiewicz and Kosiba 2009). It presents the results of calculated SOFM models in assessment of 
ordination and similarity of habitat conditions and the relations between soils, plants chemical properties and types of basaltoides according to TAS division (Total Alkali Silica).

The aim of the present study was to use Polypodium vulgare L. as test plant (chasmophyte) to determine the element levels in soils and types of basaltoides in selected regions of Lower Silesia.

We investigated the hypothesis that the parent rock, here types of basaltoides, would influence the contents of elements in soils and $P$. vulgare plants. We tried to verify that hypothesis by the SOFM technique using as data quantities of elements in soils and leaves of $P$. vulgare. Next, to find out, whether the applied method reflects the habitat quality, and whether the SOFM does provide a picture of influence of types of basaltoides upon chemical properties of the analyzed soils and plant populations.

\section{MATERIALS AND METHODS}

\section{Area, data and object of study}

The study area was Lower Silesia in Poland (19 948 $\mathrm{km}^{2}$ ), and archival data used accordimg to the paper by Kozłowska-Koch (1987), the manuscript of Ph.D. dissertation by Stankiewicz (1996) and the paper by Stankiewicz and Kosiba (2009). The description of Lower Silesian terri- tory in respect of systematics of the Polish soils and classification of these soils according to TAS division are given by Kozłowska-Koch (1987) and Trzciński (1989), respectively. In the latter paper, the object of interest were Polypodium vulgare $\mathrm{L}$. populations and soils formed by various types of basaltoides. Everyone of the 20 studied sites (Fig. 1) correspond with 20 soil samples and 20 plant samples of $P$. vulgare.

\section{Chemical analyses of soil and plant}

Detailed information on chemical composition of the types of basaltoides from 89 sites $\left(\mathrm{Al}_{2} \mathrm{O}_{3}, \mathrm{CaO}, \mathrm{FeO}\right.$, $\mathrm{Fe}_{2} \mathrm{O}_{3}, \mathrm{~K}_{2} \mathrm{O}, \mathrm{MgO}, \mathrm{MnO}, \mathrm{Na}_{2} \mathrm{O}, \mathrm{P}_{2} \mathrm{O}_{5}, \mathrm{SiO}_{2}$ and $\mathrm{TiO}_{2}$ ), of the soils from 20 samples $(\mathrm{Cd}, \mathrm{Co}, \mathrm{Cu}, \mathrm{Fe}, \mathrm{Mn}, \mathrm{Mo}, \mathrm{Ni}$, $\mathrm{Pb}, \mathrm{S}, \mathrm{Ti}$ and $\mathrm{Zn}$ ) and plants from 20 samples $(\mathrm{Ca}, \mathrm{Cd}, \mathrm{Co}$, $\mathrm{Cu}, \mathrm{Fe}, \mathrm{K}, \mathrm{Mg}, \mathrm{Mn}, \mathrm{Mo}, \mathrm{N}, \mathrm{Ni}, \mathrm{P}, \mathrm{Pb}, \mathrm{S}, \mathrm{Ti}$ and $\mathrm{Zn}$ ), the preparation of material for chemical analyses and the methods of determination of chemical components are presented in papers by Kozłowska-Koch (1987), Stankiewicz (1996) and Stankiewicz and Kosiba (2009), respectively.

In consideration of the current Regulation of the Ministry of Environmental from the 9th of July 2004 in matter of wild growing and protected plants (Dz. U. nr 168, poz. 1764), samples for chemical analysis were not taken. However, according to earlier Regulations of the Ministry of Environmental Protection, Natural Resources and Forestry

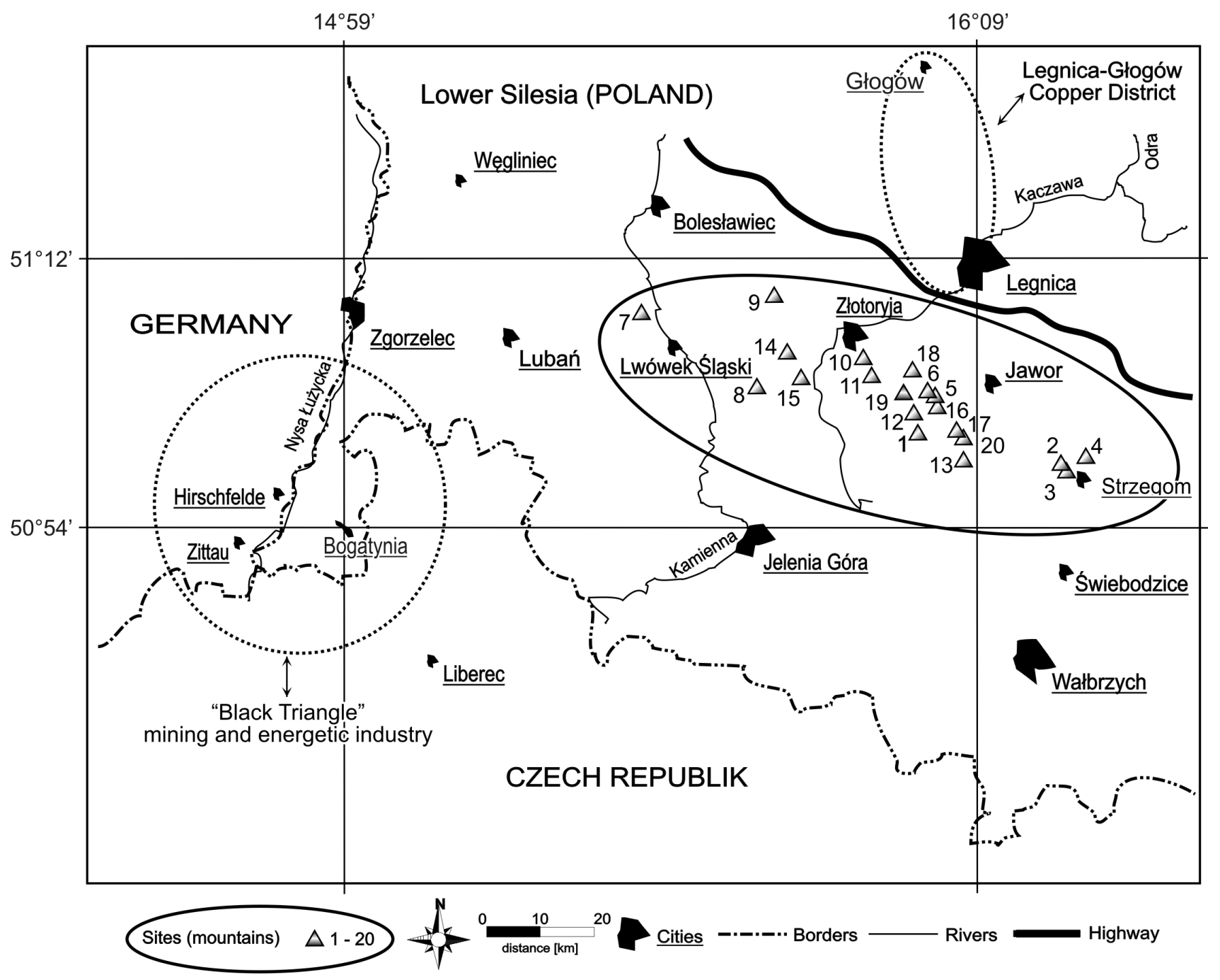

Fig. 1. Localization of sampling sites in the area of Lower Silesia. 
it was possible and among others for that reason, archival data were used.

\section{Statistical analyses}

The obtained results of chemical analyses of soil and plant samples were expressed as arithmetic mean, standard deviation $( \pm \mathrm{SD})$, minimum, maximum and variability coefficient (V) values. On the basis of archival data the statistical analyses were performed. The fitting distribution of the empirical data was verified to the normal one by the Shapiro-Wilk's test, and the homogeneities of variances were checked up by Levene's test. In case of normal distribution of investigated features the statistical-mathematical verification of results was based on parametrical tests, whereas in case of deviation from normal distribution nonparametrical tests were used. Hence, the one-way ANOVA with the F-test (ANOVA) and Kruskal-Wallis (K-W) test of ranks ANOVA for many independent samples were used, and the relationships between elements contents in soils and plants are presented by Spearman's correlation coefficient $\left(\mathrm{r}_{\mathrm{S}}\right)$.

The SOFMs for each examined case were used, i.e. for classification of types of basaltoides according to TAS division, for classification of soils and populations examined in respect of contents of chemical elements. Generally, the structure of the SOFM consists of two layers of neurons connected by weight, the input layer consists of 20 input neurons and every neuron is represented by 11 chemical components of basalts, 11 and 16 chemical elements of soils and plants, respectively. Finally, the Kohonen's topological map $5 \times 5$ has been designed. The output layer consisted of 25 neurons visualized by hexagonal cells. The obtained Kohonen's topological maps showed the neurons or groups of neurons activated by the particular investigated cases. The scheme of SOFM with Kohonen's algorithm, details on training of the network and references are presented by Stankiewicz and Kosiba (2009).

The verification of the obtained results was carried out at significance level of 0.05 according to the statistical methods and principles given by Sokal and Rohlf (2003). For all calculations, the STATISTICA 9.0 program (StatSoft, Inc. 2009) was used.

\section{RESULTS AND DISCUSSION}

\section{Analysis of variance and relationships}

The examined soils (Table 1) and $P$. vulgare populations (Table 2) differ significantly between themselves in respect of elements contents (ANOVA, $\mathrm{F}=86.2 \div 1404.8>\mathrm{F}_{0.05}$; df1 $=19$, df $2=40=1.3$ and K-W, $\chi^{2}>\chi_{0,05 ; \mathrm{df}=19}^{2}=30.1$, respec tively). Results showed a wide range of variability coefficients between the soils (from $14 \%$ for Ti to $46 \%$ for $\mathrm{Cd}$ and $\mathrm{Cu}$ ) and between populations (from $3 \%$ for $\mathrm{K}$ to $71 \%$ for $\mathrm{Cd}$ ).

Average values of elements contents in soils and plants do not exceed the range values in different types of surface soils and various plants (Markert 1992; Kabata-Pendias

TABLE 1. Descriptive statistical parameters of elements' contents in soils $\left(\mathrm{mg}^{*} \mathrm{~kg}^{-1}\right)$ from sites in Lower Silesia area.

\begin{tabular}{|c|c|c|c|c|c|c|c|c|c|c|c|}
\hline $\begin{array}{c}\text { No. } \\
\text { of sites }\end{array}$ & $\mathrm{Cd}$ & Co & $\mathrm{Cu}$ & $\mathrm{Fe}$ & $\mathrm{Mn}$ & Mo & $\mathrm{Ni}$ & $\mathrm{Pb}$ & $\mathrm{S}$ & $\mathrm{Ti}$ & $\mathrm{Zn}$ \\
\hline 01 & 0.23 & 28 & 29 & 123523 & 369 & 0.29 & 21 & 31 & 913 & 1229 & 183 \\
\hline 02 & 0.21 & 26 & 25 & 41410 & 342 & 0.28 & 18 & 38 & 1407 & 1259 & 195 \\
\hline 03 & 0.21 & 21 & 20 & 42497 & 331 & 0.26 & 28 & 38 & 1380 & 1257 & 175 \\
\hline 04 & 0.23 & 28 & 29 & 119202 & 373 & 0.30 & 26 & 30 & 892 & 1241 & 181 \\
\hline 05 & 0.20 & 31 & 31 & 99751 & 403 & 0.25 & 33 & 37 & 1384 & 1424 & 189 \\
\hline 06 & 0.40 & 14 & 27 & 120287 & 185 & 0.20 & 46 & 29 & 660 & 1434 & 192 \\
\hline 07 & 0.49 & 12 & 26 & 110550 & 163 & 0.20 & 41 & 36 & 631 & 1420 & 190 \\
\hline 08 & 0.45 & 17 & 33 & 100834 & 213 & 0.18 & 31 & 23 & 811 & 1956 & 177 \\
\hline 09 & 0.53 & 13 & 28 & 102990 & 161 & 0.24 & 48 & 30 & 759 & 1435 & 169 \\
\hline 10 & 0.58 & 15 & 31 & 101910 & 177 & 0.27 & 46 & 33 & 773 & 1579 & 185 \\
\hline 11 & 0.62 & 28 & 11 & 41418 & 413 & 0.25 & 22 & 31 & 865 & 1441 & 81 \\
\hline 12 & 0.61 & 21 & 7 & 55762 & 404 & 0.25 & 28 & 24 & 908 & 1413 & 79 \\
\hline 13 & 0.66 & 26 & 8 & 55776 & 396 & 0.22 & 21 & 28 & 1024 & 1414 & 80 \\
\hline 15 & 0.21 & 26 & 25 & 42496 & 340 & 0.28 & 27 & 38 & 1431 & 1251 & 194 \\
\hline 16 & 0.13 & 12 & 15 & 57621 & 173 & 0.20 & 43 & 8 & 841 & 1556 & 127 \\
\hline 17 & 0.12 & 11 & 14 & 68420 & 162 & 0.18 & 41 & 7 & 820 & 1455 & 119 \\
\hline 18 & 0.42 & 18 & 43 & 84639 & 253 & 0.22 & 35 & 21 & 493 & 1601 & 170 \\
\hline 19 & 0.44 & 15 & 46 & 94357 & 214 & 0.20 & 32 & 22 & 1086 & 1662 & 173 \\
\hline 20 & 0.43 & 16 & 47 & 97599 & 203 & 0.17 & 30 & 17 & 796 & 1863 & 169 \\
\hline Mean & 0.4 & 20 & 27 & 83256 & 275 & 0.23 & 33 & 27 & 935 & 1485 & 157 \\
\hline$\pm \mathrm{SD}$ & \pm 0.2 & \pm 6.5 & \pm 12 & \pm 29312 & \pm 97 & \pm 0.04 & \pm 9.1 & \pm 9.2 & \pm 271 & \pm 209 & \pm 41 \\
\hline Min. & 0.1 & 11 & 7 & 41410 & 161 & 0.17 & 18 & 7 & 493 & 1229 & 79 \\
\hline Max. & 0.7 & 31 & 48 & 123523 & 413 & 0.30 & 48 & 38 & 1431 & 1956 & 195 \\
\hline $\mathrm{V}[\%]$ & 46 & 33 & 46 & 35 & 35 & 17 & 28 & 34 & 29 & 14 & 26 \\
\hline
\end{tabular}




\begin{tabular}{|c|c|c|c|c|c|c|}
\hline ส & ஜि & $m+1$ & ¿ి & $\mathscr{q}$ & $\vec{\sim}$ & \\
\hline$F$ & 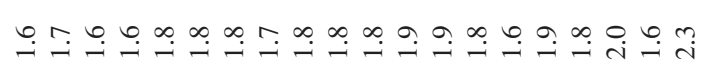 & $\stackrel{\infty}{\rightarrow} \stackrel{n}{+}$ & $\stackrel{\circ}{\circ}$ & $\tilde{i}$ & $\cong$ & \\
\hline n & 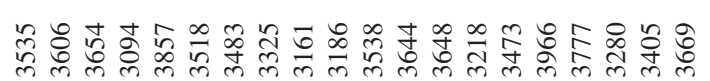 & 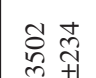 & gे & ৪ & $r$ & \\
\hline 2 & 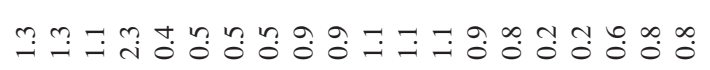 & 每 & ฮั & $\underset{n}{n}$ & in & \\
\hline$a$ & 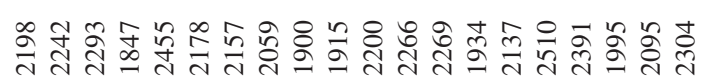 & $\underset{\sigma}{2} \frac{\infty}{++1}$ & $\underset{\infty}{\stackrel{f}{\infty}}$ & $\stackrel{0}{2}$ & $\infty$ & \\
\hline zz & 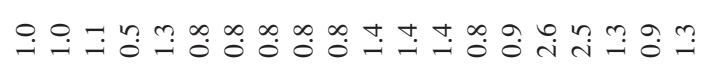 & $\stackrel{n}{n}$ & $\because$ & $\stackrel{\bullet}{i}$ & f & \\
\hline z & 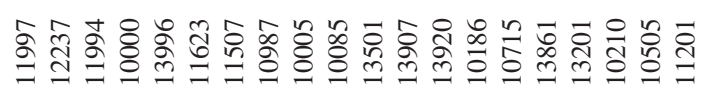 & 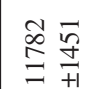 & 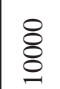 & 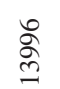 & $\simeq$ & \\
\hline$\sum^{\circ}$ & 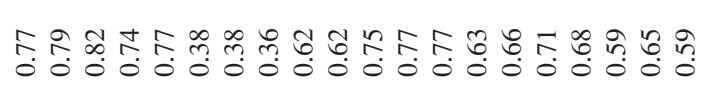 & $\mid \begin{array}{l}n \\
0 \\
0 \\
0 \\
0 \\
+1\end{array}$ & ֻొ? & $\stackrel{0}{\infty}$ & $\overline{4}$ & \\
\hline$\Sigma$ & 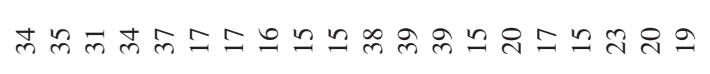 & 党 & $\because$ & ले & $\infty$ & * \\
\hline$\sum^{\infty 0}$ & 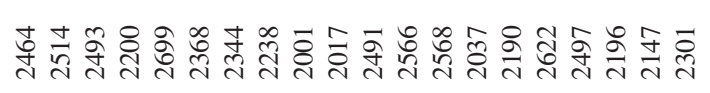 & 文 & $\overline{\mathrm{d}}$ & ڤ్రి & $a$ & \\
\hline$x$ & 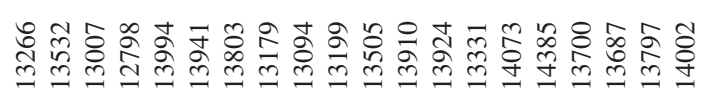 & 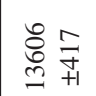 & $\begin{array}{l}\infty \\
\stackrel{\Xi}{\simeq}\end{array}$ & $\underset{\infty}{\infty}$ & $m$ & \\
\hline 里 & 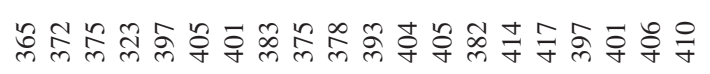 & 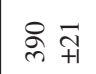 & ते & $\hat{\ni}$ & 6 & \\
\hline z & 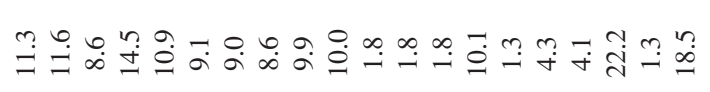 & 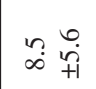 & $\stackrel{m}{m}$ & $\underset{\text { İ }}{\mathrm{y}}$ & 8 & \\
\hline 8 & 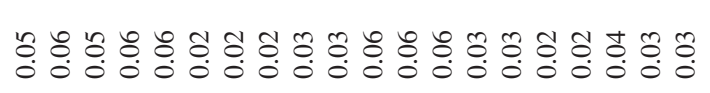 & $\frac{0}{0} \stackrel{0}{0}$ & $\stackrel{0}{0}$ & $\stackrel{8}{\circ}$ & F & \\
\hline$\Xi$ & 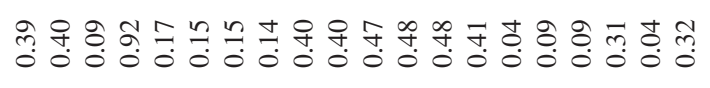 & 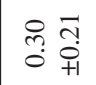 & $0_{0}^{0}$ & $\tilde{\sigma}$ & 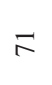 & \\
\hline$\tilde{乛}$ & 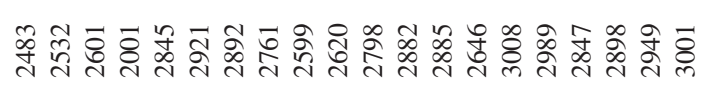 & $\begin{array}{l}\infty \\
\stackrel{\infty}{\sim} \\
\end{array}$ & $\overline{\mathrm{d}}$ & $\stackrel{0}{\infty}$ & $a$ & \\
\hline 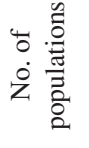 & 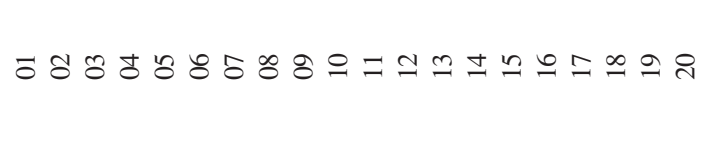 & $\sum_{\overline{0}}^{\tilde{D}}$ & $\dot{g}$ & $\stackrel{\dot{x}}{\dot{m}}$ & $\frac{\Xi}{>}$ & $=$ \\
\hline
\end{tabular}

2001a), and are in most cases similar to natural elements contents. Statistically significant positive relationships were found between elements contents in soils and plants $\left(\mathrm{r}_{\mathrm{S}}>\mathrm{r}_{\mathrm{S} \mathrm{0,05;} \mathrm{df}=18}=0.44\right)$ : $\mathrm{Cd} 0.58$, Co $0.85, \mathrm{Cu}$ 0.57, Mn 0.90, Mo 0.61, Ti 0.45 and $\mathrm{Zn} 0.71$. The contents of the elements in $P$. vulgare plants increases with higher contents of these elements in examined soils. According to Kabata-Pendias (2001a), the occurrence of various elements in the earth's crust is strongly differentiated. Their distribution and contents in soils is among other, connected with the types of basaltoides, with course of the process of soil formation, the occurrence of other elements, $\mathrm{pH}$ of soil, but also by other environmental factors which influence their level in soils. Several anthropogenic factors are known to affect the behavior of various elements in soils. Due to current anthropogenic pollution most regions are able to be enriched with some elements (Suchara et al. 2007; Kosiba 2010), especially trace (heavy) metals in the top layer of soil in the south-western industrial area of Poland (Fig. 1) (Kabata-Pendias 2001b). In order to evaluate the agricultural and ecological risks, the pool of easily bioavailable metals in a soil should be also taken under consideration. However, these forms of metals are very variable under changeable conditions of the soil-plant transfer chain. In most cases easily bioavailable forms of metals are functions of both their total contents in soils and of soil properties. 


\section{Self-organizing feature maps}

For supervised learning of the network used was the same procedure and the same size of the hexagonal topological map as in case of SOFM prepared in Figures 2 and 3 (Stan- kiewicz and Kosiba 2009). In addition the individual map in Figure 4 presents the ordination of examined sites in respect of soils chemical properties. It is included in the final SOFM model on Figure 3. The authors showed the similarity of ordination of the analysed soils in respect of ele-
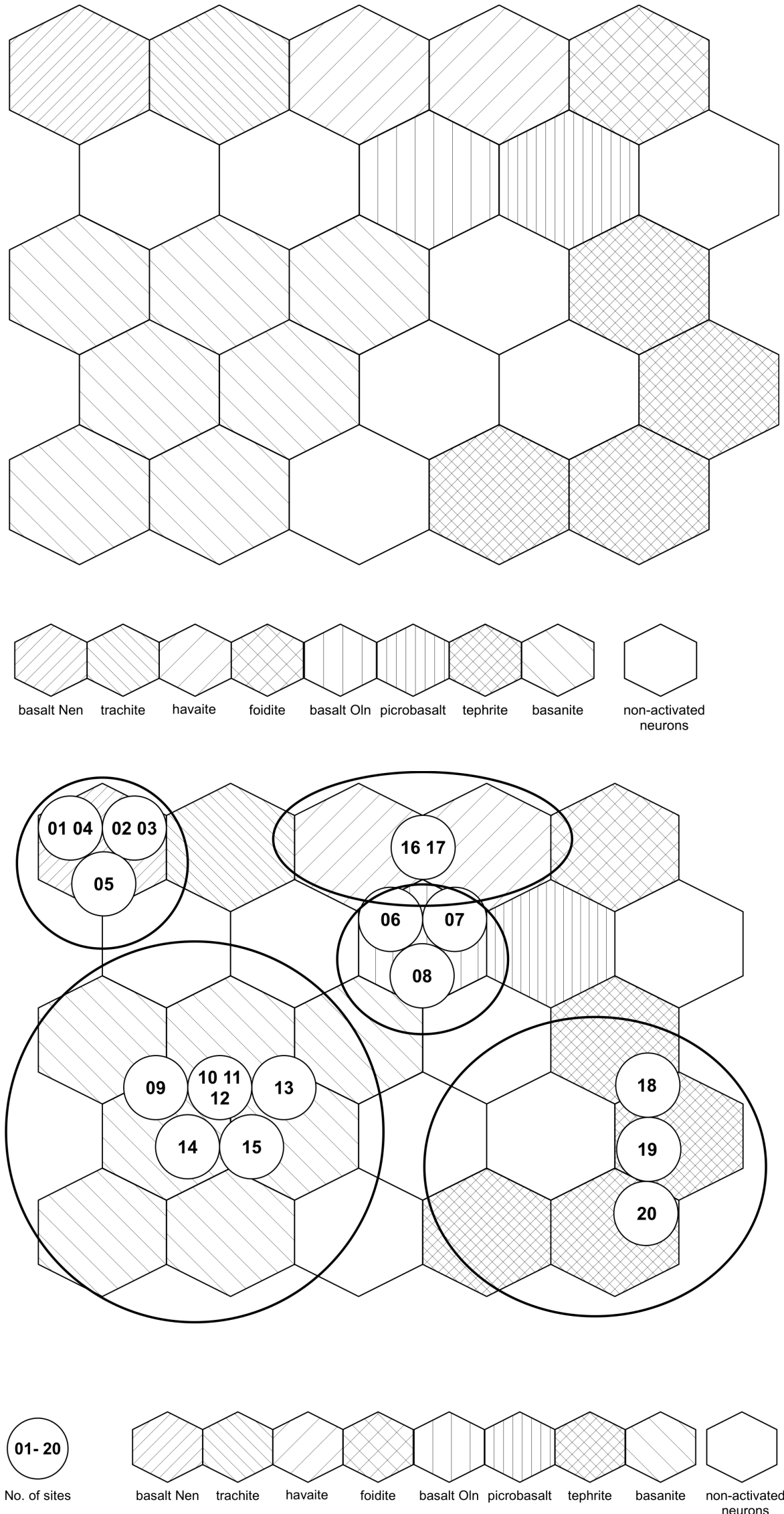

Fig. 2. SOFM of ordination of types of basaltoides in respect of chemical composition according to TAS division.

Fig. 3. SOFM of ordination of sites in respect of elements contents in soils on topological map of TAS division. 


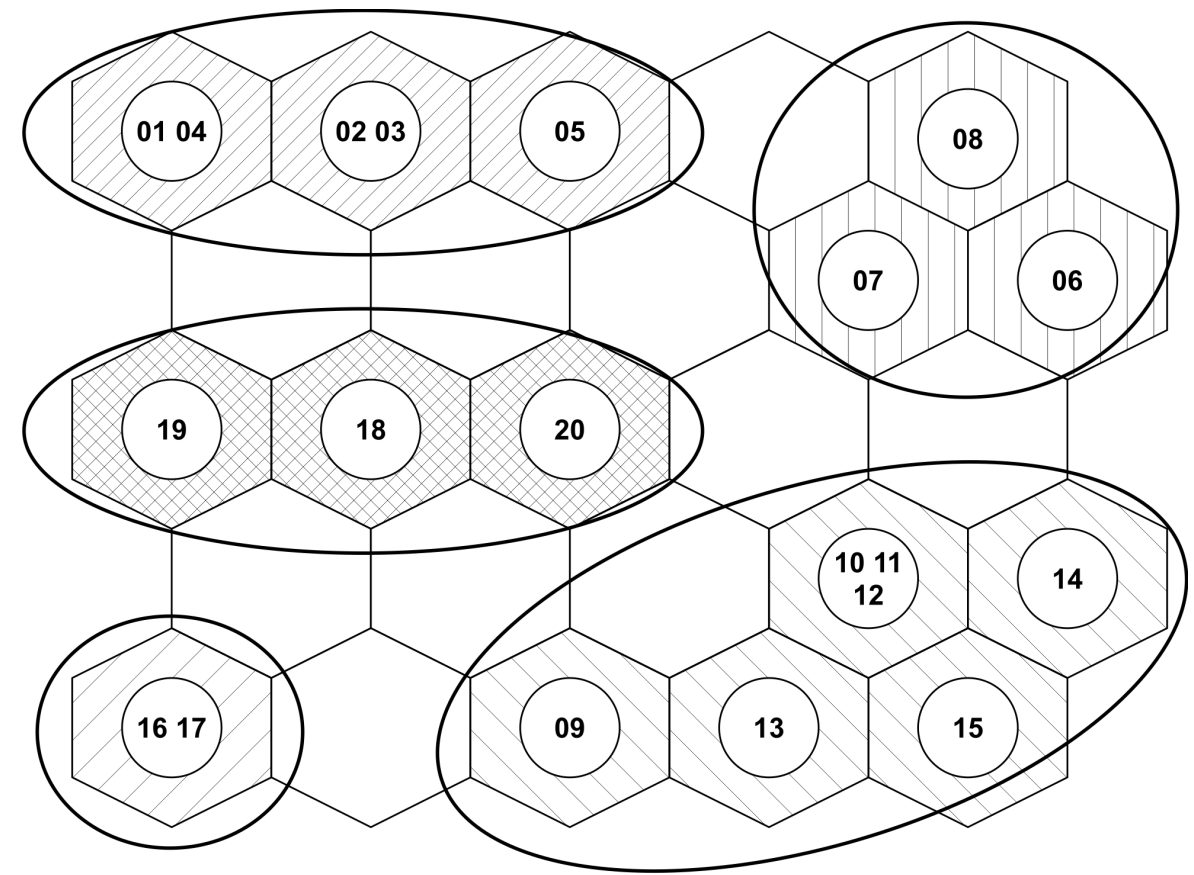

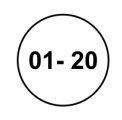

No. of sites

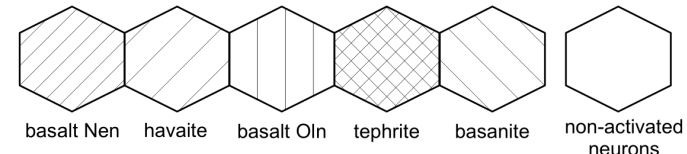

Fig. 4. SOFM of ordination of sites in respect of elements contents in soils on the topological map formed by some types of basaltoides. ments contents with chemical properties of the types of basaltoides according to the TAS division. The obtained results of these two worked out SOFM models (Figs 2 and 3) show, that the types of basaltoides exert a significant influence on content of analyzed elements in them and confirm the result of the previously carried out studies on the territory of Lower Silesia, among other by Kabata-Pendias (1965), Bogda (1973), Białowolska (1980) and Kozłowska-Koch (1987).

The archival results obtained by chemical analyses of soils and plants of $P$. vulgare were used in our paper for construction of new individual and final SOFM models. In that way, the new Kohonen's topological maps were obtained, i.e. $5 \times 5$ on which the neurons or groups of neurons activated by the particular sites are clearly visible.

Constructed was an individual SOFM model illustrating the ordination of populations of $P$. vulgare in respect of contents of the studied elements in leaves of that plant (Fig. 5). It was found that the sites and populations/group of sites and populations on topological maps (Figs 4 and 5, respectively) show a similar ordination in relation to the same and various types of basaltoides. In the resulting SOFM (Figs 4 and 5), each cell represents a neuron. Sampling soils sites and populations within one neuron are the most similar, and soils and populations in neighboring neurons are more similar than soils and populations in more distant neurons.

These two maps clearly show, that soils of examined sites developed of basalt Nen (sites: 01-05) are grouped together and are separated from the other group of soils developed of basalt Oln (sites: 07-08), basanite (sites: 09-15), havaite (sites: 16-17), tephrite (sites 18-20) (Fig. 4). The same neighbourhood of neurons and ordination showed po- pulations of $P$. vulgare growing in sites developed of basalt Nen, basalt Oln, basanite, havaite and tephrite (Fig. 5).

In effect, on the basis of results of earlier topological maps (Figs 2 and 3) as well as maps of sites and populations (Figs 4 and 5), constructed was the SOFM model for ordination of $P$. vulgare populations in respect to TAS division (Fig. 6). The results of SOFM reveal to a differentiated ordination of the populations of $P$. vulgare. Such an ordination, as shown earlier, is influenced by the significant differentiation of the examined soils and populations in respect of elements contents (Table 2) and the significant relationships of the system soil-plant $(\mathrm{Cd}, \mathrm{Co}, \mathrm{Cu}$, Mn, Mo, Ti and $\mathrm{Zn}$ ). Within one neuron the populations are most similar, whereas in the neighbouring ones less or least similar, in cases they occur in distinct neurons. The SOFM decidedly separates the particular populations, at the same time joining them into groups including the populations of highest similarity as regards both quantity and quality of the chemical composition of leaves, and these are the groups of populations: 01-05, 07-08, 09-15, 16-17 and 18-20. Neurons/groups of neurons of the populations clearly correspond with neurons/groups of neurons of types of basaltoides (Fig. 3) and TAS division (Fig. 2), i.e. basalt Nen, basalt Oln, basanite, havaite and tephrite.

In the SOFM model derived from examined sites in Lower Silesia, based on elements contents in soils and $P$. vulgare neighbouring neurons from groups which are occupied by plants growing on the soils developed of different types of basaltoides. The elements contents in these plants depend on chemical composition of types of basaltoides and correspond to TAS division.

A similar modelling of environment or habitat conditions with the use of SOFM was applied by Giraudel and Lek 

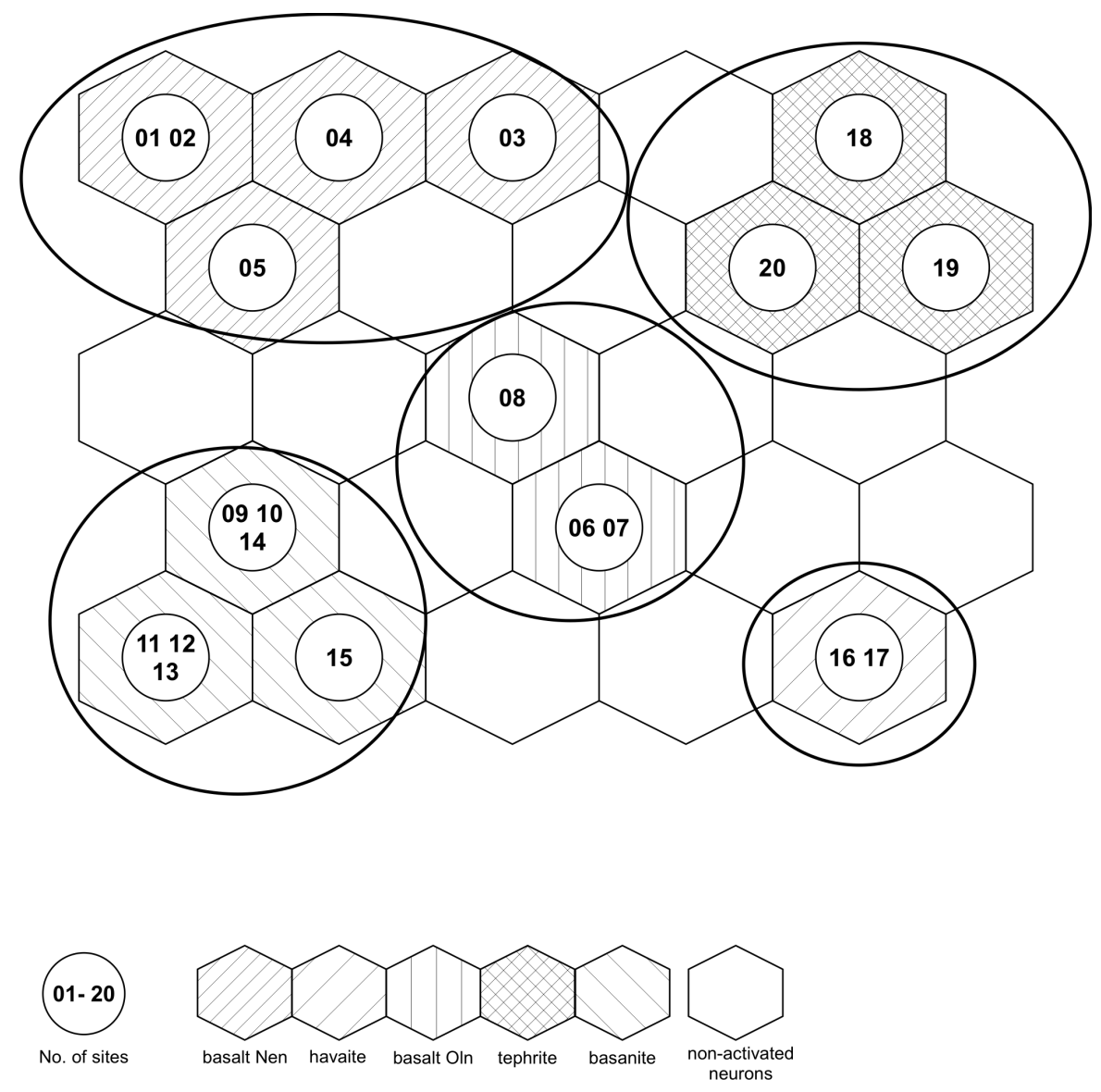

Fig. 5. SOFM of ordination of Polypodium vulgare populations in respect of elements contents in leaves on the topological map of types of basaltoides.

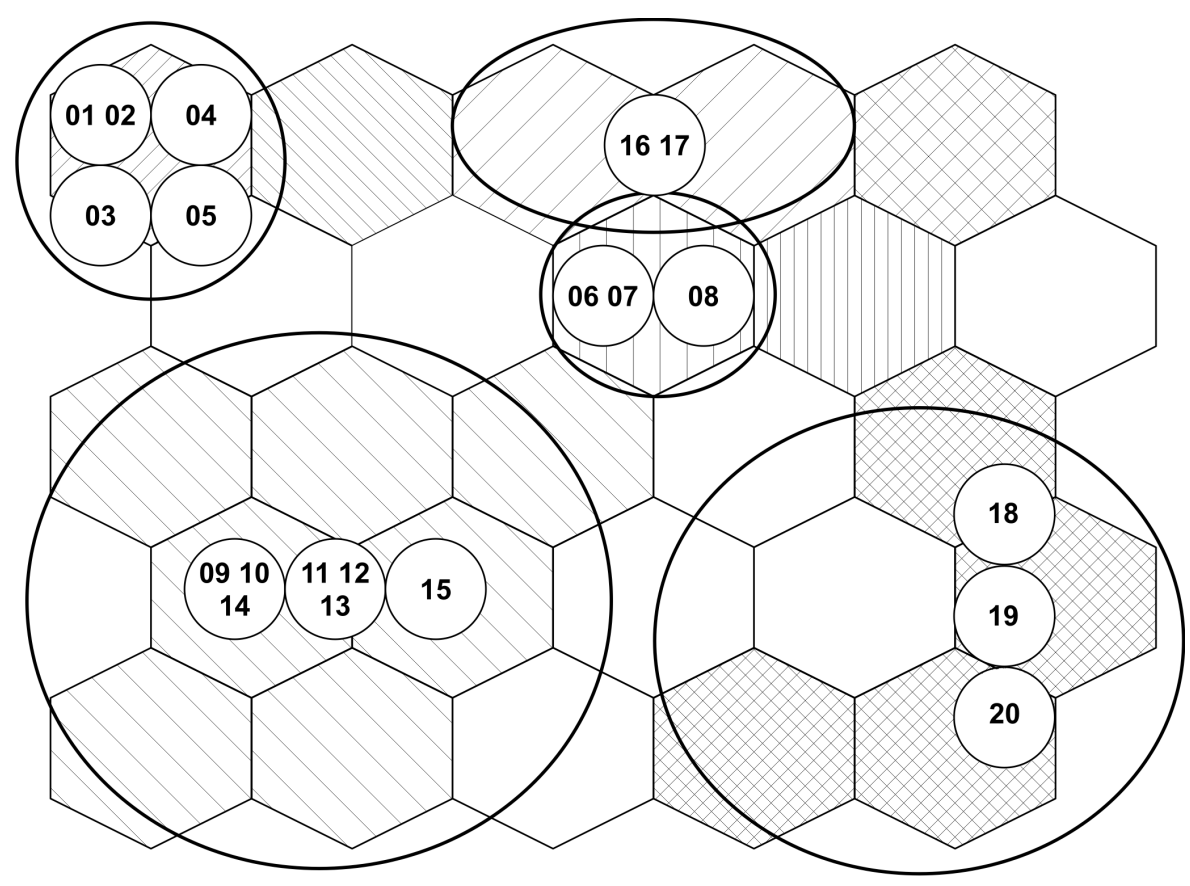

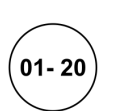

No. of sites

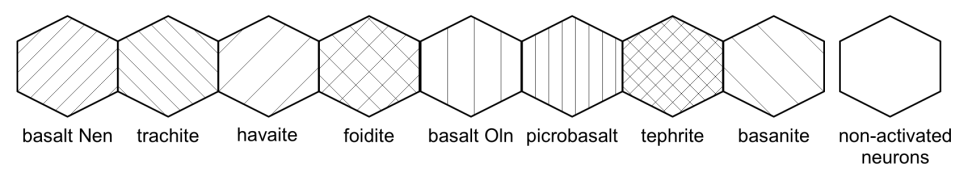

Fig. 6. SOFM of ordination of Polypodium vulgare populations in respect of elements contents in leaves on the topological map of TAS division.
(2001) for ordination of ecological communities, Lee and Scholz (2006) for wetlands, Kosiba and Stankiewicz (2007) for Utricularia species microhabitats, Samecka-Cy- merman et al. (2007) for classification of the relation between chemical compositions of aquatic bryophytes and streambeds, Samecka-Cymerman et al. (2009) and Kosiba 
(2010) in bioindication studies with various species of mosses growing around pollution sources.

The role of neural networks in ecological modelling (as well as in other kinds of environmental modelling) for ecologists and other practitioners is that there is plenty of space for experimentation and for creative use of computational tools. From a more general point of view, owing to the flexibility of self-organizing feature maps (and also other neural networks), application of SOFM in the studies proved the importance of the technique and can be used in various fields of applied ecological studies.

\section{CONCLUSIONS}

On the basis of results and all the points showed above it can be concluded, that:

- the analysed soils are significantly differentiated in respect of chemical properties which are conditioned by the type of basaltoides formed by parent rock,

- the soils and populations of Polypodium vulgare are characterized by a high variability of the analysed elements,

- as "marker" elements of the computed relationships of the system soil-plant one may accept: $\mathrm{Cd}, \mathrm{Co}, \mathrm{Cu}, \mathrm{Mn}, \mathrm{Mo}$, $\mathrm{Ti}$ and $\mathrm{Zn}$. The higher contents of these elements in soil corresponds with a significantly higher contents in leaves of Polypodium vulgare populations.

Self-organizing feature maps analysis of literature data show the effects of types of basaltoides on chemical composition of examined soils and Polypodium vulgare populations, and confirms that:

- the research has demonstrated that SOFM can be used to classify the types of basaltoides using quantity and quality data of soils and can be used as estimators for environmental conditions,

- the worked out model of SOFM for Polypodium vulgare populations in respect of chemical properties is in concordance with the model of ordination of types of basaltoides according to TAS division,

- SOFM seems fully usable in ecology and proper for phenomena and processes taking place in natural environment. It can perfectly complete various techniques for exploring data and for achieving community ordination and provide a visual way to find structures. Thus, it ought to be taken into account as a possible tool of estimation of various plants and their habitats.

\section{LITERATURE CITED}

ADAMCZYK Z. 2008. Ewolucja wulkanizmu kenozoicznego Przedgórza Rębiszowskiego (Dolny Śląsk) oraz jej wpływ na charakter petrograficzny i jakość surowca bazaltowego. Zeszyty Naukowe Politechniki Śląskiej, Górnictwo, Wydawnictwo Politechniki Ślaskiej, Gliwice, 282: pp. 244. (in Polish with English summary)

BIAŁOWOLSKA A. 1980. Geochemiczna charakterystyka niektórych bazaltoidów Dolnego Śląska i ich ultramafitowych enklaw. Arch. Miner., 36: 107-163. (in Polish with English summary)

BOGDA A. 1973. Mineralogiczne i mikromorfologiczne badania produktów wietrzenia niektórych magmowych skał macierzystych gleb występujących w Sudetach. Rocz. Gleb., 44, 2: 85132. (in Polish)
CHON T., PARK Y.S., MOON K.H., CHA E.Y. 1996. Patternizing communities by using an artificial neural network. Ecol. Model. 90: 69-78.

Dziennik Ustaw RP nr 41, poz. 214 z dnia 06.07.2004 r. Rozporządzenie Ministra Środowiska w sprawie gatunków dziko występujących roślin objętych ochroną. (in Polish)

FABISZEWSKI J., KWIATKOWSKI P. 2002. Threatened vascular plants of the Sudeten Mountains. Acta Soc. Bot. Pol., 71, 4: 339-350.

GIRAUDEL J.L., LEK S. 2001. A comparison of self-organizing map algorithm and some conventional statistical methods for ecological community ordination. Ecol. Model., 146: 329-339.

KABATA-PENDIAS A. 1965. Badania geochemiczno-mineralogiczne gleb wytworzonych z granitów i bazaltów Dolnego Śląska. Rocz. Nauk Rol., 90, 1: 1-60. (in Polish)

KABATA-PENDIAS A. 2001a. Trace Elements in Soils and Plants. Third Edition, CRC Press, USA.

KABATA-PENDIAS A. 2001b. Trace metals in soils - a current issue in Poland, In: Studies on plant ecology, Samecka-Cymerman A. (ed.). Acta. Univ. Wratisl., No. 2317, Prace Bot., 79: $13-20$.

KOHONEN T. 2001. Self-Organizing Maps. Springer-Verlag, Berlin, Heidelberg Series in Information Sciences, Vol. 30, Berlin, Springer-Verlag.

KOSIBA P. 2010. Modele ekologiczne reakcji wybranych gatunków mchów endohydrycznych na oddziaływanie zanieczyszczeń przemysłowych. Badania bioindykacyjne i populacyjne. Wydawnictwo Uniwersytetu Wrocławskiego, Wrocław, pp. 121. (in Polish with English summary)

KOSIBA P., STANKIEWICZ A. 2007. Water trophicity of Utricularia microhabitats identified by means of SOFM as a tool in ecological modelling. Acta Soc. Bot. Pol., 76, 3: 255-261.

KOZŁOWSKA-KOCH M. 1987. Klasyfikacja i nomenklatura trzeciorzędowych wulkanitów Dolnego Śląska i Śląska Opolskiego. Arch. Miner., 42: 1-107. (in Polish with English summary)

LEE B.H., SCHOLZ M. 2006. A comparative study: Prediction of constructed treatment wetland performance with k-nearest neighbors and neural networks. Water, Air Soil Pollut., 174: 279-301.

MARKERT B.A. 1992. Presence and significance of naturally occurring chemical elements of the periodic system in the plant organism and consequences for future investigations on inorganic environmental chemistry in ecosystems. Vegetatio, 103: $1-30$.

MORENO-SANCHEZ M. 2004. Graphic approach for morphometric analysis of Archaeopteris leaves. Ann. Paleontol., 90: 161-173.

MRÓZ L. 2001. Dynamika liczebności populacji storczyków na Czartowskiej Skale na Pogórzu Kaczawskim, In: Studia nad ekologią roślin, Samecka-Cymerman A. (ed.). Acta. Univ. Wratisl., No. 2317, Prace Bot., 79: 169-178. (in Polish with English summary)

RECKNAGEL F. 2001. Applications of machine learning to ecological modelling. Ecol. Model., 146: 303-310.

RAY C., KLINDWORTH K.K. 2000. Neural Networks for agrichemical vulnerability assessment of rural private wells. J. Hydrol. Eng., 5, 2: 162-171.

SAMECKA-CYMERMAN A., STANKIEWICZ. A., KOLON K., KEMPERS A.J. 2007. Self-organizing feature map (neural networks) as a tool in classification of the relations between chemical composition if aquatic bryophytes and type of streambeds in the Tatra national park in Poland. Chemosphere, 67, 5: 954-960.

SAMECKA-CYMERMAN A., STANKIEWICZ A., KOLON K., KEMPERS A.J. 2009. Bioindication of Trace Metals in Brachythecium retabulum Around a Copper Smelter in Legnica (Southwest Poland): Use of a New Form of Data Presentation In the Form of a Self-Organizing Feature Map. Arch. Environ. Contam. Toxicol., 56: 717-722. 
SCARDI M. 2001. Advances in neural network modeling of phytoplankton primary production. Ecol. Model., 146: 33-45.

SOKAL R.R., ROHLF F.J. 2003. Biometry. The principles and practice of statistics in biological research. W. H. Freeman \& Company, New York.

SOKOLOWSKI A. 2002. Metody stosowane w data mining, In: Data mining - metody i przykłady. StatSoft Polska sp. z o.o., Kraków, pp. 5-12. (in Polish)

SOKOŁOWSKI A. 2010. Estymacja i testowanie hipotez, In: Statistica w badaniach naukowych i nauczaniu statystyki. StatSoft Polska Sp. z o.o., Kraków, pp. 25-60. (in Polish)

STATSOFT, INC. 2009. Statistica (data analysis software system), version 9.0.(www.statsoft.com).

STANKIEWICZ A. 1996. Biogeochemia roślin podłoża bazaltów Gór Kaczawskich i ich Pogórza. Manuscript of Ph.D. dissertation, Biblioteka Instytutu Biologii Roślin, Wydział Nauk Biologicznych, Uniwersytet Wrocławski. (in Polish)
STANKIEWICZ A., KOSIBA P. 2009. Advances in ecological modelling of soil properties by self-organizing feature maps of natural environment of Lower Silesia (Poland). Acta Soc. Bot. Pol., 78, 2: 167-174.

SUCHARA I., MAŇKOVSKÁ B., SUCHAROVÁ J., FLOREK M., GODZIK B., RABNECZ G., TUBA Z., KAPUSTA P. 2007. Mapping of main sources of pollutants and their transport in the Visegrad space, Part I: Eight toxic metals. KLEMO spol. s r. o., (Ltd.), Zvolen, Slovak Republic.

TADEUSIEWICZ R. 2000. The application of neural networks in biotechnology and biomaterials. Prace Miner., 89: 9-17.

TADEUSIEWICZ R. 2006. Data miting jako szansa na relatywne tanie dokonywanie odkryć naukowych poprzez przekopywanie pozornie całkowicie wyeksploatowanych danych empirycznych, In: Statystyka i data miting w badaniach naukowych. StatSoft Polska Sp. z o.o., Kraków, pp. 5-30 (in Polish).

TRZCIŃSKI W. (ed.). 1989. Systematyka Gleb Polski, Roczniki Gleboznawcze, PWN, Warszawa, 40, 3/4 (in Polish). 